\title{
SALINE-SODIC SOILS RECLAMATION BY ELECTROCHEMICAL REMEDIATION TECHNIQUE
}

\author{
Samah M.S. Abdel-Aal", K.F. Moussa, A.H. Ibrahim and M.K. Abdel-Fattah \\ Soil Sci. Dept., Fac. Agric., Zagazig Univ., Egypt
}

\begin{abstract}
Soil columns technique was conducted to assess the possibility of saline-sodic soils reclamation by using gypsum (G), sulfur (S), rice straw compost (RSC) and direct current (DC). Soil samples were collected from Sahl El-Hossinia, El-Sharkia Governorate, Egypt. The treatments were control (leaching alone), G, S, RSC, DC, DC $+\mathrm{G}, \mathrm{DC}+\mathrm{S}$ and DC + RSC. Results showed pronounced decrease in soil bulk density, $\mathrm{pH}, \mathrm{EC}_{\mathrm{e}}$ and exchangeable sodium percentage for all treatments. The most effective treatment was $\mathrm{DC}+\mathrm{G}$. Efficiency of treatments was in the following order: $\mathrm{DC}+\mathrm{G}>$ $\mathrm{DC}+\mathrm{S}>\mathrm{DC}+\mathrm{C}>\mathrm{DC}>\mathrm{G}>\mathrm{S}>\mathrm{C}>$ Control.
\end{abstract}

Key words: Gypsum, sulfur, compost and direct current.

\section{INTRODUCTION}

Salt affected soils categorized into three groups, saline soils, sodic and saline sodic soils (Brady and Weil, 2002). These soils are commonly found in arid and semi arid regions, characterized by high amount of sodium that deteriorate soil structure, reduce water intake, and cause fertility problems leading to reduction in crop production (Suarez, 2001). Greater than $8 \times 10^{8}$ ha of world land are affected, either by salinity $\left(3.97 \times 10^{8}\right.$ ha $)$ or sodicity $\left(4.34 \times 10^{8}\right.$ ha) (FAO, 2000), both constitutes about $6 \%$ of the world's total land area. The problem of saltaffected soils is not new but its intensity has been increasing due to poor management practices and inappropriate amelioration procedures.

Sodic and saline-sodic soils are reclaimed by replacing the exchangeable sodium with calcium and flush sodium out of the system. This is commonly accomplished by adding gypsum (Oster et al., 1993; Tuna et al., 2007; Ghafoor et al., 2008; Murtaza et al., 2009), sulfur or sulfuric acid (Horneck et al., 2007), organic matter (Joachim et al., 2007; Dhanushkodi and Subrahmaniyan, 2012), and/or direct current (Niroumand et al., 2012; Cho et al., 2011). In all

\footnotetext{
* Corresponding author. Tel. : +201203620535

Email address: mohammedkamal8@yahoo.com
}

cases, adequate drainage must be maintained for both sodic and saline-sodic soils to flush sodium out of the soil system.

In this context, Khan et al. (2010) found a positive significant improvement in saline-sodic soil properties, i.e., EC, SAR and $\mathrm{pH}$ in response to gypsum applied in ridges, farmyard manure and agricultural practices that resulted in an increase in wheat grain yield by $42 \%$ over control. Besides, Cha-um et al. (2011) evaluated the efficiency of the same treatment on remediation of saline soil and found that rice recorded $79.6 \%$ spikelet fertility in response to gypsum and FYM against $46.4 \%$ for the same soil without the use of gypsum and FYM. In the same behavior, Abdel-Fattah (2011 and 2012) detected a pronounced decreases in $\mathrm{EC}, \mathrm{pH}$, SAR, ESP and bulk density and increased in hydraulic conductivity and infiltration rate in saline-sodic soil due to the application of gypsum and two types of compost either they applied solely or in combination, compared with control. He added that combined treatments were more efficient. The same results obtained by Abou Youssef (2001) and Manzoor et al. (2001). 
Direct current technologies have been used by Zhou et al. (2005), Altaee et al. (2008), Ryu et al. (2009), Park et al. (2009), Kim et al. (2009a and b), Baek et al. (2009) and Niroumand et al. (2012).

The electromigration processes, namely the transportation of ions toward oppositvely charged electrodes, is the major mechanism for separating and removing salts (Eid et al., 2000 a and b), Manokararajah and Sri Ranjan (2005a and b), Jia et al. (2005 and 2006) and Ryu et al. (2009). Electrokinetic treatment was performed by Cho et al. (2011) using column techniques to evaluate the effect of electric current duration, they detected that after electric current duration the electrical conductivity (EC) of the soil decreased to $1.93 \mathrm{dSm}^{-1}$ from an initial value of $5.3 \mathrm{dSm}^{-1}$ and the distribution of sulfate was similar to that of EC. Abdel-Fattah (2014), who used a column techniques to asses the efficiency of electrochemical process in reclaim salinesodic soils, he concluded that leaching using direct current (DC) led to improvement of the chemical properties of saline sodic soils and the efficiency of reclamation was in the following order: 9-Volt $>3$-Volt $>$ leaching alone (nonDC treatment).

The present study has been conducted to evaluate the effectiveness of electrochemical processes and some traditional amendments (i.e. gypsum, sulfur and compost) on reclaiming saline-sodic soil.

\section{MATERIALS AND METHODS}

The goal of this experiment was assess the possibility of reclamation of saline-sodic soils using electrochemical technique with or without traditional amendments i.e., gypsum " $G$ ", sulfur "S" and rice straw compost "C". Soil samples were collected from Sahl El-Hossinia, ElSharkia Governorate, Egypt. Samples were collected from $30 \mathrm{~cm}$ surface layer; air dried, crushed, mixed and passed through a $2 \mathrm{~mm}$ sieves and analyzed for their physical and chemical properties (Table 1). Polyvinyl chloride (cylindroids tubes) of $40 \mathrm{~cm}$ height and $16 \mathrm{~cm}$ inside diameter were used. The bottom of each tube was sealed with perforated a mesh nylon screen and glass wool. Acid-washed inert sand (pre-washed with $\mathrm{HCl}$ then water) was placed on the tube bottom to make a $5 \mathrm{~cm}$ layer of the column. Soil was packed in tubes so as to a soil column $30 \mathrm{~cm}$ height and a bulk density of $1.40 \mathrm{Mg} \mathrm{m}^{-3}$, this required a quantity of soil of about $8 \mathrm{~kg}$ of crushed air-dried soil per column. The five $\mathrm{cm}$ over on top of soil column was leaved to give sufficient space for addition of water used for leaching process.

The soil amendments used in this experiment were, gypsum, sulfur and rice straw compost. Gypsum amount was calculated based on the gypsum requirement (GR) equation (USDA, 1954) taking in consideration a required final value of exchangeable sodium percent $\left(\mathrm{ESP}_{\mathrm{f}}\right)$ of $10 \%$, and an actual exchangeable sodium percent $\left(\mathrm{ESP}_{\mathrm{i}}\right)$ initial value of $26.58 \%$ found in the soil (see Table 1). The equation is as follows:

$$
\mathrm{GR}=\frac{\mathrm{ESP}_{\mathrm{i}}-\mathrm{ESP}_{\mathrm{f}}}{100} \times \mathrm{CEC} \times 1.72
$$

Where:

GR: gypsum requirement (ton/fad.),

ESP $_{i}$ : initial ESP of the soil (actual ESP of the soil),

ESP $_{f}$ : final ESP of the soil (ESP required to be reached by reclamation)

CEC: cation exchange capacity $\left(\mathrm{cmol}_{\mathrm{c}} \mathrm{kg}^{-1}\right)$.

The equivalent amount for sulfur was calculated according to FAO (1988) as follows: amount of sulfur $=$ GR $\times 0.19$. Rice straw compost was added at a rate of $1 \%$ by weight. All former amendments were mixed homogeneously within soil matrix $(30 \mathrm{~cm}$ depth) before packed in tubes.

$2.5 \mathrm{~cm}$ diameter $\times 30 \mathrm{~cm}$ height mild steel tubes were inserted on the soil column to serve as electrodes, i.e. cathode and anode (Fig. 1). Distance between cathode and anode was $10 \mathrm{~cm}$. Electrodes were contacted to a nine voltage direct current power supply (DC). The experiment included eight treatments as follows; control (leaching alone), G, S, RSC, DC, DC + $\mathrm{G}, \mathrm{DC}+\mathrm{S}$ and $\mathrm{DC}+\mathrm{RSC}$. Each treatment consisted of three replicates.

Soil experimental columns were leached with water having EC $1.06 \mathrm{dS} / \mathrm{m}$. Leaching was done 
Table 1. Some physical and chemical properties of the studied soil

\begin{tabular}{|c|c|c|c|}
\hline Property & Value & Property & Value \\
\hline Particle size distribution (\%) & & Soluble ions, EC and pH & \\
\hline - Sand & 18.30 & - EC $\left(\mathrm{dSm}^{-1}\right)$ (Soil paste extract) & 85.53 \\
\hline - Silt & 35.20 & - pH (Soil suspension 1:2.5) & 8.31 \\
\hline - Clay & 46.50 & - Soluble ions $\left(\mathrm{mmol}_{\mathrm{c}} \mathrm{l}^{-1}\right)$ & \\
\hline - Texture class & Clay & - $\mathrm{Na}^{+}$ & 697.92 \\
\hline Soil moisture characteristics (\%) & & - $\mathrm{K}^{+}$ & 17.21 \\
\hline - Saturation percent & 31.30 & - $\mathrm{Ca}^{+2}$ & 55.56 \\
\hline - Field capacity & 15.70 & - $\mathrm{Mg}^{+2}$ & 341.21 \\
\hline - Wilting point & 6.83 & - $\mathrm{Cl}^{-}$ & 856.14 \\
\hline Density (Mg. $\left.\mathrm{m}^{-3}\right)$ & & - $\mathrm{HCO}_{3}^{-}$ & 7.77 \\
\hline - Bulk density & 1.40 & - $\mathrm{SO}_{4}=$ & 247.99 \\
\hline - Total porosity $(\%)$ & 49.10 & - SAR & 49.55 \\
\hline Organic matter $\left(\mathrm{g} \mathrm{kg}^{-1}\right)$ & 5.30 & Exchangeable cations, CEC and ESP & \\
\hline \multirow[t]{6}{*}{$\mathrm{CaCO}_{3}\left(\mathrm{~g} \mathrm{~kg}^{-1}\right)$} & 75.0 & - $\mathrm{Na}^{+}$ & 6.82 \\
\hline & & - $\mathrm{K}^{+}$ & 3.99 \\
\hline & & - $\mathrm{Ca}^{+2}$ & 7.85 \\
\hline & & - $\mathrm{Mg}^{+2}$ & 7.00 \\
\hline & & - $\quad$ CEC $\left(\mathrm{cmolc} \mathrm{kg}^{-1}\right)$ & 29.69 \\
\hline & & - ESP & 26.58 \\
\hline
\end{tabular}

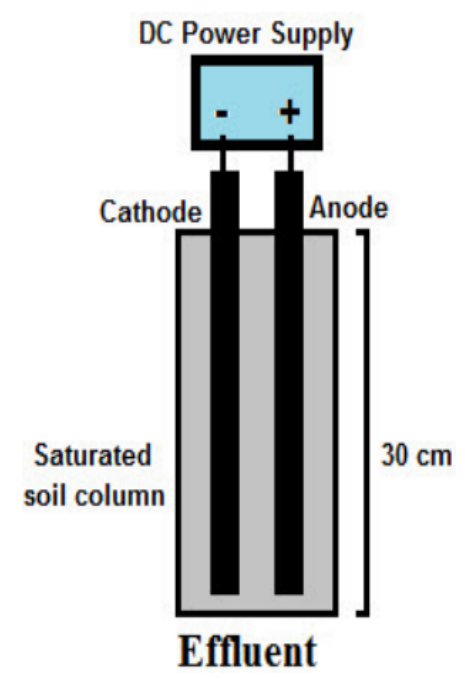

Fig. 1. Schematic drawing electrochemical experimental system according to Abdel-Fattah (2014) 
using intermittent method so as to add portions to the already saturated soil columns and obtain leachates equal to the added portions. The leachate from each soil column, equal to the added water leachate (1000 $\mathrm{ml}$ per column), was collected. Six collections were performed and leachates were analyzed for salt content. After termination of leaching processes, soil columns were separated into two segments, 0-15 and $15-30 \mathrm{~cm}$. Each segment was air dried, crushed and sieved through a 2-mm sieve and analyzed according to Baruah and Barthakur (1997), Jackson (1967) and Page et al. (1982).

\section{RESULTS AND DISCUSSION}

Some soil chemical and physical properties after termination of leaching process at the 0-15 $\mathrm{cm}$ and $15-30 \mathrm{~cm}$ layers as affected by different treatments is given in Table 2, several facts are self-evident from this table. First, soil reaction $(\mathrm{pH})$ values are decreased in all treatments compared with control and initial value, where the significant differences ( $\mathrm{p}$ value at 0.05 ). The $\mathrm{pH}$ decreased followed the order: $\mathrm{DC}+\mathrm{G}>$ $\mathrm{DC}+\mathrm{S}>\mathrm{DC}+\mathrm{RSC}>\mathrm{DC}>\mathrm{G}>\mathrm{S}>\mathrm{C}>$ Control. The lowest $\mathrm{pH}$ value (7.50) is resulted from $\mathrm{DC}+\mathrm{G}$ treatment whereas control (i.e. leaching alone) treatment gave the highest $\mathrm{pH}$ value (8.31). With respect to soil $\mathrm{pH}$ as affected by soil depth, the results show that the soil $\mathrm{pH}$ values increase with soil depth with no significant differences, where the upper soil depth $(0-15 \mathrm{~cm})$ gave the lowest $\mathrm{pH}$ value (7.67) and the lower one $(15-30 \mathrm{~cm})$ gave highest $\mathrm{pH}$ value (7.69) with no significant differences. The combination effect between treatments and soil depth reveal that $\mathrm{DC}+\mathrm{G}$ treatment in upper soil layer gave the lowest soil $\mathrm{pH}$ value of 7.49 whereas control treatment in lower soil layer gave the highest $\mathrm{pH}$ value (8.32) with no significant differences. There was a tendency for a decrease in $\mathrm{pH}$ values due to treatments. This finding may be attributed to soil high buffering capacity due to the clayey texture and high $\mathrm{CaCO}_{3}$ content.

Moreover, results revealed that gypsum expose a relatively greater effect on reducing soil $\mathrm{pH}$. The decrease in soil $\mathrm{pH}$ due to gypsum application was probably due to a combination of more than one factor, mainly the replacement of sodium by calcium and the formation of neutral salts with $\mathrm{SO}_{4}{ }^{=}$. The decrease in soil $\mathrm{pH}$ may decrease sodium concentration as a fraction of other cations. This decreasing may be due to removal of exchangeable sodium from the soil column. In this context, gypsum solubility is also enhanced due to increased activity coefficient of calcium and sulfate as a result of increased ionic strength of solution and the formation of the sodium sulfate ion pair. Besides, large quantities of $\mathrm{CO}_{2}$, which evolved during leaching process the decomposition of the organic matter such as compost by activity of microorganisms resulting increase of organic and inorganic acids, thereby decreasing soil $\mathrm{pH}$. Similar observation were also reported by Wassif et al. (1992), Ismail et al. (1992), Sabri et al. (1993) and Abdel-Fattah (2012 and 2014).

Regarding electrochemical effect on soil $\mathrm{pH}$, it can be noticed that electrolysis of the water under the applied of voltage caused a change in $\mathrm{pH}$. Reactions can be described as follows:

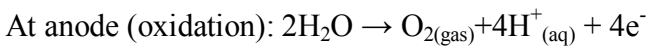

At cathode (reduction): $4 \mathrm{H}_{2} \mathrm{O}+4 \mathrm{e}^{-} \rightarrow 2 \mathrm{H}_{2 \text { (gas) }}+4 \mathrm{OH}^{-}($aq)

Hydrogen and hydroxide ions generated at the anode and cathode were transported toward the opposite charged electrodes by electromigration. Thus, soil $\mathrm{pH}$ would decrease at the anode and increase at the cathode (Niroumand et al., 2012).

Remarkable effect of different treatments on soil electrical conductivity of saturation extract $\left(\mathrm{EC}_{\mathrm{e}}\right)$. The data present in Table 2 reveal that all treatments showed a pronounced decreased in soil $\mathrm{EC}_{\mathrm{e}}$ values compared to initial value (85.53 $\mathrm{dSm}^{-1}$, see Table 1) with significant differences ( $\mathrm{P}$ value at 0.05$)$. The $\mathrm{EC}_{\mathrm{e}}$ decreased was in the following order: $\mathrm{DC}+\mathrm{G}>\mathrm{DC}+\mathrm{S}>\mathrm{DC}+\mathrm{C}>\mathrm{DC}$ $>\mathrm{G}>\mathrm{S}>\mathrm{C}>$ Control. The lowest ECe (3.18 $\mathrm{dSm}^{-1}$ ) was detected from $\mathrm{DC}+\mathrm{G}$ treatment whereas control (i.e. leaching alone) treatment gave the highest one $(5.55 \mathrm{dS} / \mathrm{m})$. The $\mathrm{EC}_{\mathrm{e}}$ values of soil were $3.18,3.80,3.89,4.42,4.45$, $4.77,4.81$ and $5.55 \mathrm{dS} / \mathrm{m}$ for the $\mathrm{DC}+\mathrm{G}, \mathrm{DC}+$ $\mathrm{S}, \mathrm{DC}+\mathrm{C}, \mathrm{DC}, \mathrm{G}, \mathrm{S}, \mathrm{C}$ and Control, respectively, which surpassed the control treatment by $42.5,31.53,29.9,20.36,19.81$, 14.05 and $13.33 \%$, respectively. With respect to soil $\mathrm{EC}_{\mathrm{e}}$ as affected by soil depth, data revealed that $\mathrm{EC}_{\mathrm{e}}$ increased by increased soil depth with no significant differences. Upper soil depth $(0$ $15 \mathrm{~cm})$ gave the lowest $\mathrm{EC}_{\mathrm{e}}$ value 
Table 2. Some physical and chemical properties of studied soil after termination of leaching process as affected by different treatments

\begin{tabular}{|c|c|c|c|c|c|c|c|c|c|c|c|c|c|c|}
\hline \multirow{2}{*}{\multicolumn{2}{|c|}{ The Effected Factor }} & \multirow[t]{2}{*}{$\mathbf{p H}$} & \multirow{2}{*}{$\begin{array}{c}\text { EC, } \\
\text { dS.m }^{-1}\end{array}$} & \multicolumn{4}{|c|}{ Soluble cations, mmolc $\mathrm{I}^{-1}$} & \multicolumn{3}{|c|}{ Soluble Anions, mmolc $\mathrm{I}^{-1}$} & \multirow[t]{2}{*}{ SAR } & \multirow[t]{2}{*}{ ESP } & \multirow[t]{2}{*}{ BD, $\mathrm{Mg} \mathrm{m}^{-3}$} & \multirow[t]{2}{*}{ TP (\%) } \\
\hline & & & & $\mathrm{Ca}^{2+}$ & $\mathrm{Mg}^{2+}$ & $\mathrm{Na}^{+}$ & $\mathbf{K}^{+}$ & $\mathrm{HCO}_{3}{ }^{=}$ & $\mathrm{Cl}^{-}$ & $\mathrm{SO}_{4}{ }^{=}$ & & & & \\
\hline \multicolumn{15}{|c|}{ Treatments effect } \\
\hline \multicolumn{2}{|c|}{ Leaching alone (control) } & 8.31 & 5.55 & 22.49 & 4.47 & 24.83 & 3.71 & 22.00 & 12.65 & 20.85 & 6.76 & 17.92 & 1.41 & 46.79 \\
\hline \multicolumn{2}{|c|}{ Gypsum } & 7.62 & 4.45 & 18.03 & 3.59 & 19.91 & 2.97 & 17.64 & 10.14 & 16.72 & 6.06 & 12.13 & 1.18 & 55.47 \\
\hline \multicolumn{2}{|l|}{ Sulfur } & 7.64 & 4.77 & 19.33 & 3.85 & 21.34 & 3.18 & 18.91 & 10.88 & 17.91 & 6.27 & 13.08 & 1.19 & 55.09 \\
\hline \multicolumn{2}{|l|}{ Compost } & 7.69 & 4.81 & 19.49 & 3.88 & 21.52 & 3.21 & 19.07 & 10.97 & 18.06 & 6.30 & 10.81 & 1.34 & 49.43 \\
\hline \multicolumn{2}{|l|}{ Direct current (DC) } & 7.58 & 4.42 & 17.92 & 3.57 & 19.78 & 2.95 & 17.53 & 10.08 & 16.61 & 6.03 & 10.46 & 1.15 & 56.60 \\
\hline \multicolumn{2}{|c|}{ Direct current + Gypsum } & 7.50 & 3.18 & 12.89 & 2.56 & 14.23 & 2.12 & 12.6 & 7.25 & 11.95 & 5.12 & 8.96 & 1.14 & 56.98 \\
\hline \multicolumn{2}{|c|}{ Direct current + Sulfur } & 7.52 & 3.8 & 15.39 & 3.06 & 16.99 & 2.53 & 15.05 & 8.66 & 14.26 & 5.59 & 9.38 & 1.16 & 56.23 \\
\hline \multicolumn{2}{|c|}{ Direct current + Compost } & 7.55 & 3.89 & 15.78 & 3.14 & 17.42 & 2.6 & 15.43 & 8.88 & 14.63 & 5.66 & 13.94 & 1.24 & 53.21 \\
\hline \multicolumn{2}{|c|}{$\mathbf{L S D}_{5 \%}$} & 0.01 & 0.21 & 0.84 & 0.17 & 0.93 & 0.14 & 0.82 & 0.47 & 0.78 & 0.15 & 0.78 & 0.02 & 0.59 \\
\hline \multicolumn{15}{|l|}{ Soil depth effect } \\
\hline \multicolumn{2}{|l|}{$1^{\text {st }}$ depth, cm (D1) } & 7.67 & 4.33 & 17.56 & 3.49 & 19.38 & 2.89 & 17.17 & 9.88 & 16.27 & 5.97 & 11.76 & 1.21 & 54.34 \\
\hline \multicolumn{2}{|l|}{$2^{\text {nd }}$ depth, cm (D2) } & 7.69 & 4.39 & 17.77 & 3.54 & 19.62 & 2.93 & 17.40 & 10.00 & 16.46 & 6.01 & 12.41 & 1.24 & 53.21 \\
\hline \multicolumn{2}{|l|}{ LSD $5 \%$} & NS & NS & NS & NS & NS & NS & NS & NS & NS & NS & 039 & 0.01 & 0.297 \\
\hline \multicolumn{15}{|l|}{ Interaction effects } \\
\hline \multirow[t]{2}{*}{ Control } & D1 & 8.29 & 5.49 & 22.25 & 4.42 & 24.56 & 3.67 & 21.77 & 12.52 & 20.61 & 6.73 & 11.53 & 1.40 & 17.17 \\
\hline & D2 & 8.32 & 5.61 & 22.74 & 4.52 & 25.1 & 3.75 & 22.26 & 12.79 & 21.06 & 6.8 & 10.78 & 1.42 & 46.42 \\
\hline Sulfur & D1 & 7.63 & 4.72 & 19.14 & 3.81 & 21.13 & 3.15 & 18.73 & 10.77 & 17.73 & 6.24 & 5.57 & 1.17 & 55.09 \\
\hline & D2 & 7.60 & 4.82 & 19.52 & 3.89 & 21.55 & 3.21 & 19.1 & 10.99 & 18.08 & 6.3 & 7.76 & 1.20 & 54.72 \\
\hline Compost & D1 & 7.67 & 4.77 & 19.33 & 3.85 & 21.34 & 3.18 & 18.91 & 10.88 & 17.91 & 6.27 & 7.00 & 1.33 & 49.81 \\
\hline & D2 & 7.70 & 4.85 & 19.66 & 3.91 & 21.7 & 3.23 & 19.23 & 11.06 & 18.21 & 6.32 & 7.08 & 1.35 & 49.06 \\
\hline Direct current (DC) & D1 & 7.57 & 4.34 & 17.6 & 3.51 & 19.43 & 2.9 & 17.22 & 9.91 & 16.31 & 5.98 & 4.38 & 1.13 & 57.36 \\
\hline & D2 & 7.59 & 4.5 & 18.24 & 3.63 & 20.13 & 3 & 17.85 & 10.26 & 16.89 & 6.09 & 5.04 & 1.17 & 55.85 \\
\hline DC + Gypsum & D1 & 7.49 & 3.13 & 12.67 & 2.52 & 13.99 & 2.09 & 12.40 & 7.13 & 11.74 & 5.08 & 5.37 & 1.11 & 58.11 \\
\hline & D2 & 7.51 & 3.23 & 13.1 & 2.61 & 14.46 & 2.16 & 12.82 & 7.37 & 12.14 & 5.16 & 6.48 & 1.16 & 56.23 \\
\hline DC + Sulfur & D1 & 7.51 & 3.78 & 15.31 & 3.05 & 16.9 & 2.52 & 14.99 & 8.61 & 14.18 & 5.58 & 5.17 & 1.14 & 56.98 \\
\hline & D2 & 7.53 & 3.82 & 15.47 & 3.08 & 17.07 & 2.54 & 15.13 & 8.7 & 14.33 & 5.61 & 5.36 & 1.18 & 55.47 \\
\hline DC + Compost & D1 & 7.54 & 3.86 & 15.64 & 3.11 & 17.27 & 2.58 & 15.31 & 8.8 & 14.49 & 5.64 & 7.38 & 1.23 & 53.58 \\
\hline & D2 & 7.56 & 3.93 & 15.91 & 3.16 & 17.57 & 2.62 & 15.57 & 8.95 & 14.74 & 5.69 & 8.38 & 1.25 & 52.83 \\
\hline LSD $5 \%$ & & NS & $\mathrm{NS}$ & NS & $\mathrm{NS}$ & NS & $\mathrm{NS}$ & NS & $\mathrm{NS}$ & NS & $\mathrm{NS}$ & $\mathrm{NS}$ & $\mathrm{NS}$ & NS \\
\hline
\end{tabular}

$\mathrm{SAR}=$ Sodium adsorption ratio $\quad \mathrm{ESP}=$ Exchangeable sodium percentage $(\%) \quad \mathrm{BD}=\mathrm{Bulk}$ density $\quad \mathrm{TP}=\mathrm{Total}$ porosity 
$(4.33 \mathrm{dS} / \mathrm{m})$ whereas the lower one $(15-30 \mathrm{~cm})$ gave highest $\mathrm{EC}_{\mathrm{e}}$ value $(4.39 \mathrm{dS} / \mathrm{m})$. while the combination effect between treatments and soil depth, data reveal that $\mathrm{DC}+\mathrm{G}$ treatment in upper soil depth gave the lower value of soil ECe (3.13 $\mathrm{dS} / \mathrm{m}$ ) whereas control treatment in lower soil depth gave the highest value $(5.61 \mathrm{dS} / \mathrm{m})$ with no significant differences.

However, results showed that gypsum was more effective for decreasing $\mathrm{EC}_{\mathrm{e}}$. This fact may be due to positively effect of gypsum on soil physical properties such as hydraulic conductivity and infiltration rate. Consequently, the movement of water within soil profile would increase, resulting in more leaching efficient and excess salts removing. These results are in agreement with those obtained by Tripathi and Singh (1974), Abrol et al. (1988), Srivastava and Srivastava (1993) and Abdel-Fattah (2012). On the other hand, DC led to accelerate the dissolution of gypsum mending, which accumulated on the exchange sites and improved physical properties of soil like aggregation thus reducing the ECe. This results supported by the work of You-Jin et al. (2013) and Abdel-Fattah (2014). Regarding to soluble ions (cations and anions) and SAR, results showed that soluble ions and SAR took a similar trend to that of $\mathrm{EC}_{\mathrm{e}}$.

Regarding to exchangeable sodium percentage (ESP) as affected by different amendments, data in Table 2 show a pronounced decreased in ESP values compared to $17.92 \%$ of the control value with significant differences ( $\mathrm{p}$ value at 0.5 ). The ESP decreased was arranged in the following order: $\mathrm{DC}+\mathrm{G}>\mathrm{DC}+\mathrm{S}>\mathrm{DC}+\mathrm{C}>\mathrm{DC}>\mathrm{G}>\mathrm{S}>$ $\mathrm{C}>$ Control. The main effect shows that $\mathrm{DC}+\mathrm{G}$ treatment gave the lowest ESP $(8.96 \%)$ whereas control treatment gave the highest one $(17.92 \%)$. The ESP values of soil were $8.96,9.38,10.46$, $10.81,12.13,13.08,13.94$ and $17.92 \%$ for the $\mathrm{DC}+\mathrm{G}, \mathrm{DC}+\mathrm{S}, \mathrm{DC}+\mathrm{C}, \mathrm{DC}, \mathrm{G}, \mathrm{S}, \mathrm{C}$ and Control, respectively, which decreased under control treatment by 50, 47.66, 41.62, 39.68, $32.31,27.01$ and $22.21 \%$, respectively. With respect to soil ESP as affected by soil depth, data showed augmenting increase of ESP with soil depth with significant differences. Upper soil depth $(0-15 \mathrm{~cm})$ gave the lowest ESP value $(11.76 \%)$ whereas the lower one $(15-30 \mathrm{~cm})$ gave highest ESP value (12.41\%). In this context it could detect that control treatment in lower soil depth $(15-30 \mathrm{~cm})$ gave the highest value of soil ESP $(18.34 \%)$ whereas $D C+G$ treatment in upper soil depth $(0-15 \mathrm{~cm})$ gave the lowest value $(8.53 \%)$ with no significant differences.

Regarding to soil Bulk density (BD) and total Porosity (TP) as affected by different experimental amendments, results in (Table 2) declare that there is a reduction in $\mathrm{BD}\left(\mathrm{Mg} \cdot \mathrm{m}^{-3}\right)$ values compared to $1.40 \mathrm{Mg} \cdot \mathrm{m}^{-3}$ for the initial value with significant differences ( $p$ value at $0.05)$. The $\mathrm{BD}$ was decreased in the following order: $\mathrm{DC}+\mathrm{G}>\mathrm{DC}+\mathrm{S}>\mathrm{DC}>\mathrm{G}>\mathrm{S}>\mathrm{DC}+\mathrm{C}>$ $\mathrm{C}>$ Control. Once more $\mathrm{DC}+\mathrm{G}$ treatment gave the lowest BD (1.14 Mg. $\left.\mathrm{m}^{-3}\right)$ whereas control (i.e. leaching alone) treatment gave the highest one $\left(1.41 \mathrm{Mg} \cdot \mathrm{m}^{-3}\right)$. The BD values of soil were $1.14,1.15,1.16,1.18,1.19,1.24,1.34$ and 1.41 Mg. $\mathrm{m}^{-3}$ for the $\mathrm{DC}+\mathrm{G}, \mathrm{DC}+\mathrm{S}, \mathrm{DC}, \mathrm{G}, \mathrm{S}$, $\mathrm{DC}+\mathrm{C}, \mathrm{C}$ and Control, respectively. Treatments decreased under control treatment by 19.14 , $18.43,17.73,16.31,15.6,12.06$ and $4.96 \%$, respectively.

With respect to soil BD as affected by soil depth, results declared that BD increase with soil depth with significant differences. However Upper soil depth $(0-15 \mathrm{~cm})$ gave the lowest BD value $\left(1.21 \mathrm{Mg} \cdot \mathrm{m}^{-3}\right)$ whereas the lower one (15$30 \mathrm{~cm})$ gave highest BD value $\left(1.24 \mathrm{Mg} \cdot \mathrm{m}^{-3}\right)$. Concerning the combination effect between treatments and soil depth, results reveal that $\mathrm{DC}+\mathrm{G}$ treatment in upper soil depth $(0-15 \mathrm{~cm})$ gave the lowest value of BD $\left(1.11 \mathrm{Mg} \cdot \mathrm{m}^{-3}\right)$ whereas control treatment in lower soil depth $(15-30 \mathrm{~cm})$ gave the highest value BD (1.42 $\mathrm{Mg} \cdot \mathrm{m}^{-3}$ ) with no significant differences.

Moreover results show that treatments included gypsum are more effective in reducing BD than sulfur treatments. This finding may be attributed to the need of sulfur mending to be oxidized and convert into sulfuric acid, which would cause dissolution of $\mathrm{Ca}$-bearing minerals in soil. Results also refer to that compost has a positive effect on $\mathrm{BD}$ reduction. These results are in agreement with that of Abdel-Aziz et al. (1998) and Wahadan et al. (1999).

Data illustrated in Table 2 showe that treatments include DC are more effective in reducing $\mathrm{BD}$ than non-DC treatments. This 
finding may be attributed to DC treatments led to accelerate the dissolution of Ca-bearing minerals in soil and gypsum mending, which accumulations on the exchange sites and improved soil aggregation thus reducing the BD. This result is supported by work of Jia et al. (2006), Ryu et al. (2009) and Cho et al. (2011). With respect to soil total porosity (TP) as affected by different amendments, results in Table 2 indicate that total porosity (TP) values increased as a result of applied DC in combination with amendments. Generally, TP increased by about $8.94 \%$, compared to control. However, the TP results showed the opposite trend as the $\mathrm{BD}$.

\section{Conclusion}

The results of this work confirmed that $\mathrm{DC}+\mathrm{G}$ could markedly improve saline-sodic soil chemical and physical properties compared with other used treatments. Efficiency of treatments were $\mathrm{DC}+\mathrm{G}>\mathrm{DC}+\mathrm{S}>\mathrm{DC}+\mathrm{C}>\mathrm{DC}>\mathrm{G}>\mathrm{S}>\mathrm{C}$ $>$ Control. The repressive combined effect of DC and $G$ might be attributed to the positive effect of $G$ replacing power by sodium and to the DC, which accelerate the dissociation of $\mathrm{Ca}^{2+}$ bearing minerals and flushing $\mathrm{Na}^{+}$out of the soil system.

\section{REFERENCE}

Abdel-Aziz, S.M., F.S. Salem, M.M.A. Reda and L.A. Hussien (1998). Influence of some amendments on the clayey soil properties and crop production. Fayoum J. Agric. Res. and Dev., 12 (1): 196-204

Abdel-Fattah, M.K. (2011). Some biological and chemical methods for salt affected soils reclamation. Ph.D. Thesis, Fac. Agric. Zagazig Univ. Egypt.

Abdel-Fattah, M.K. (2012). Role of gypsum and compost in reclaiming saline-sodic soils. IOSR J. Agric. and Vet. Sci., (IOSR-JAVS), 1 (3): 30-38.

Abdel-Fattah, M.K. (2014). Reclaiming salinesodic soils using electrochemical processes: a case study from Sahl El-Tina Plain, Egypt, 65 (2): 51-58
Abou Youssef, M.F. (2001). Use Phosphogypsum fortified as a soil amendment for saline sodic soil in El-Salhiya Plain, Zagazig.

Abrol, I.P., S.P. Yadav and F.I. Massoud (1988). Salt affected soils and their management. FAO soils bulletin, soil resources management and conservation service, FAO Land and Water Develop. Division, 39: 131139.

Altaee, A., R. Smith and S. Mikhalovsky (2008). The feasibility of decontamination of reduced saline sediments from copper using the electrokinetic process. J. Environ. Manag., 88: 1611-1618.

Baek, K., D.H. Kim., S.W. Park., B.G.T. Ryu and J.S. Yang (2009). Electrolyte conditioning - enhanced electrokinetic remediation of arsenic-contaminated mine tailing. J. Hazardous Mat., 161: 457-462.

Baruah, T.C. and H P. Barthakur (1997). A Text Book of Soil Analysis. Vikas Publishing House Pvt Ltd., New Delhi.

Brady, N.C. and R.R. Weil (2002). The Nature and Properties of Soils. $13^{\text {th }}$ Ed. Prentice Hall, Upper Saddle River, N.J. 881 [On reserve in the Woodward library]

Cha-um, S., Y. Pokasombat and C. Kirdmanee (2011). Remediation of salt-affected soil by gypsum and farmyard manure importance for the production of Jasmine rice, Aust. J. Crop Sci., 5 (4): 458-465.

Cho, J.M., D.H. Kim, J.S. Yang and K. Baek (2011). Electrokinetic restoration of sulfateaccumulated saline greenhouse soil. CleanSoil, Air, Water, 39 (12): 1036-1040.

Dhanushkodi, V. and K. Subrahmaniyan (2012). Soil management to increase rice yield in salt affected coastal soil a review. Int. J. Res. Chem. Environ., 2: 1-5.

Eid, N., D. Slack and D Larson (2000a). Nitrate electromigration in sandy soil: closed system response. J. Irrigation and Drainage Engin., 126: 389-397.

Eid, N., W. Elshorbagy, D. Larson and D. Slack. (2000b). Electro-migration of nitrate in sandy soil. J. Hazardous Mat., 79: 133-149. 
FAO (1988). Salt affected soils and their management. Soils Bulletin No. 39 Roma.

FAO (2000). Land and plant nutrition management service. Online paper. Webs sit: http://www.fao.org/ag/agl/agll/prosoil/salt.ht m. Problem soils database.

Ghafoor, A., G. Murtaza, B. Ahmad and T.H.M. Boers (2008). Evaluation of amelioration treatments and economic aspects of using saline-sodic water for rice and wheat production on salt-affected soils under arid land conditions. Irrigation and Drainage, 57: 424-434.

Horneck, D.A., J.W. Ellsworth, B.G. Hopkins, D.M. Sullivan and R.G. Slevens (2007). Managing salt-affected soils for crop production. PNW, 601.

Ismail, A.S., A.A. Sakr and S.A. Radwan (1992). Effect of leaching and certain amendments on chemical properties of an alluvial soil and the growth on barley. $2^{\text {nd }}$ Afr. soil Sci. Soc. Conf.

Jackson, M.L. (1967). Soil Chemical Analysis. Prentice Hall of India private. Limited New Delhi.

Jia, X., D. Larson, D. Slack and J. Walworth, (2005). Electrokinetic control of nitrate movement in soil. Engin. Geol., 77: 273-283.

Jia, X., D.L. Larson and W.S. Zimmt (2006). Effective nitrate control with electrokinetics in sand soil. Transactions of the ASAE, 49: 803- 809.

Joachim, H.J.R., P. Makoi and A. Ndakidemi (2007). Reclamation of sodic soils in northern Tanzania, using locally available organic and inorganic resources. Afr. J. Biotech., 6 (16): 1926-1931.

Khan, M.J., M.T. Jan, A.U. Khan, M. Arif and M. Shafi (2010). Management of saline sodic soils through cultural practices and gypsum. Pak. J. Bot., 42: 4143 - 4155.

Kim, D.H., B.G. Ryu, S.W. Park, C.I. Seo and K. Baek (2009b). Electrokinetic remediation of $\mathrm{Zn}$ and Ni-Contaminated soil. J. Hazardous Mat., 165: 501-505.
Kim, D.H., C.S. Jeon, K. Baek, S.H. Ko and J.S. Yang (2009a). Electrokinetic remediation of fluorine-contaminated soil. Conditioning of Anolyte. Hazardous Mat., 161 (1): 565-569.

Manokararajah, K. and R. Sri Ranjan (2005a). Electrokinetic denitrification of nitrates in a nitrate contaminated silty loam soil. Appl. Engin. Agric., 21(3): 541-549.

Manokararajah, K. and R. Sri Ranjan (2005b). Electrokinetic retention, migration and remediation of nitrates in silty loam soil under hydraulic gradients. Engin. Geol., 77 (3-4): 263-272.

Manzoor, A., N.M.H. Salim and B.H. Niazi (2001). Use of chemical amendments for reclamation of saline-sodic soils. Int. J. Agric. Biol., 3 (3): 305-307.

Murtaza, G., B. Murtaza, H.M. Usman and A. Ghafoor (2009). Amelioration of saline-sodic soil using gypsum and low quality water in following sorghum-berseem crop rotation. Int. J. Agric. Biol., 15: 640-648.

Niroumand, H., R. Nazir and K.A. Kassim (2012). The performance of electrochemical remediation technologies in soil mechanics. Int. J. Electrochem. Sci., 7 : 5708- 5715

Oster, J.D., H. Lieth and A.A Al-Masoom, (1993). Sodic soil reclamation. Towards the rational use of high salinity tolerant plants. Veg. Sci., 1: 20 - 27.

Page, A.L., R.H. Miller and D.R. Keeney (1982). Methods of Soil Analysis: Part 2, Chemical and Microbiological Properties. Agronomy Series No 9, Ame. Soc. Agron., Madison, WI.

Park, S.W., J.Y. Lee., J.S. Yang, K.J. Kim and K. Baek (2009). Electrokinetic remediation of contaminated soil with waste-lubricantoils and zinc. J. Hazardous Mat., 169 : 11681172.

Ryu, B.G., S.W. Park, K. Baek and J.S. Yang (2009). Pulsed electrokinetic decontamination of agricultural lands around abandoned mines contaminated with Heavy Metals. Separation Sci. and Technol., 44: 2421-2436.

Sabri, R.E.A., M.F. Ghoneim, R.K. Rabie and H.A. Abdel-Magid (1993). Effect of soil 
conditioners and irrigation regime on the growth and nutrient uptake by Alfafa plants. Egypt J. Soil Sci., 33 (1): 73-84.

Srivastava, A.K. and O.P. Srivastava (1993). Cation exchange capacity in relation to soil sodicity in Amended saline sodic soil J. Indain Soc. of Soil Sci., 41 (1): 155-157

Suarez, D.L. (2001). Sodic soil reclamation: Modeling and field study. Aust. J. Soil Res., 39: $1225-1246$.

Tripathi, B.R. and V. Singh (1974). Evaluation of gypsum requirement method for assessing exchangeable sodium in salt affected soils. J. Indian Soci. Soil Sci., 22 (2): 162-167.

Tuna, A.L., C. Kaya, M. Ashraf, H. Altunlu, I. Yokas and B. Yagmur (2007). The effects of calcium sulphate on growth, membrane stability and nutrient uptake of tomato plants grown under salt stress. Environ. Exp. Bot., 59: 173-178.
USDA (1954) Diagnosis and Improvement of Saline and Alkali Soils. Agriculture Hand Book No. 60 US Gov. Printing Office, Washington.

Wahadan, A.A., S.A. El-Gendi and A.S. AbdelMawgoud (1999). Amelioration techniques for sodic soil in Al-Fayoum Oasis. Egypt. J. Soil Sci., 39 (2) : 199-210.

Wassif, M.M., A.M. El-Gala, M.A. Mostafa and S.E. El-Maghraby (1992). Effect of elemental sulphur and water salinity levels on ion solubility in two calcareous soils. $2^{\text {nd }}$ Afr. Soil Sci. Soc., Conf.

You-Jin, L., C. Jeong-Hee, L. Hyun-Goo and H. Tae-Hyun (2013). Electrokinetic remediation of saline soil using pulse power. Environ. Engin. Sci., 30 (3): 133.

Zhou, D.-M., C.-F Deng, A.N. Alshawabkeh and L. Cang (2005). Effects of catholyte conditioning on electrokinetic extraction of copper from mine tailings. Environ. Int., 31 : 885-890.

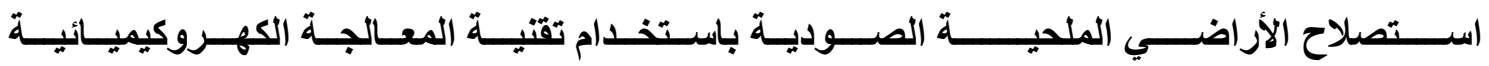 \\ سماح محمد سعيد عبد العال ـ كرم فؤاد موسى ـ أحمد حسين إبراهيم ـ محمد كمال عبد الفتاح

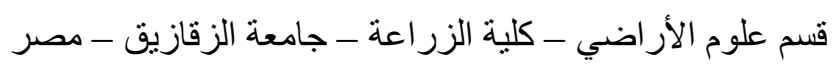

تم تنفيذ تجربة أعمدة لتقييم إمكانية استصلاح الأراضي الملحية الصودية باستخدام الجبس، الكبريت، كمبوست قش التش

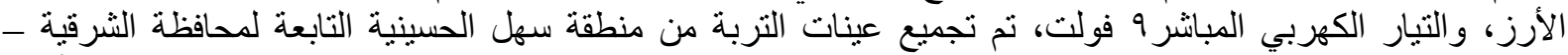

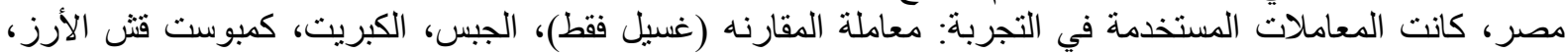

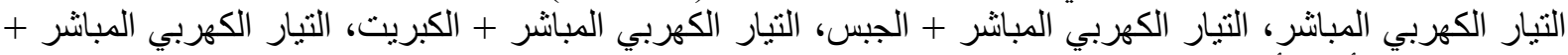

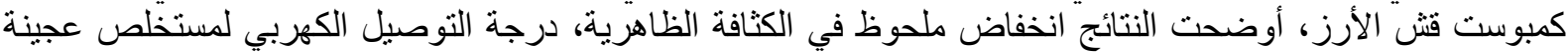

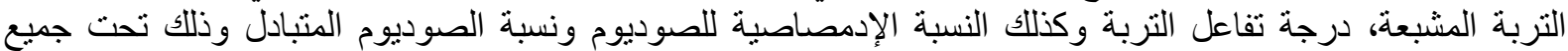

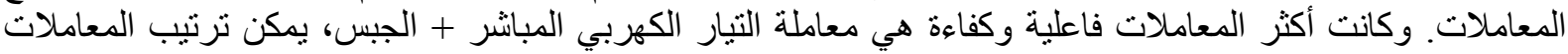

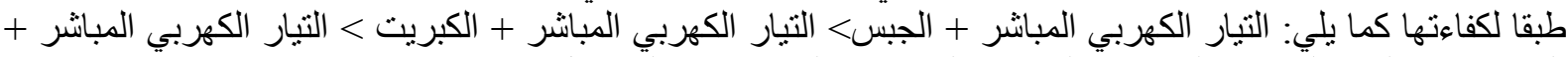

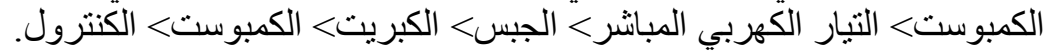

